\title{
Detection of ovine herpesvirus-2 in clinical cases of sheep-associated malignant catarrhal fever in balinese cattle and apparently healthy sheep in East Nusa Tenggara
}

\author{
Agus Wiyono ${ }^{1 *}$, Harimurti Nuradji ${ }^{1}$, Maxs UE Sanam ${ }^{2}$, Yohanes TRMR Simarmata ${ }^{2}$, and \\ Rini Damayanti ${ }^{1}$ \\ ${ }^{1}$ Indonesian Research Center for Veterinary Sciences, Ministry of Agriculture, Bogor, Indonesia. \\ ${ }^{2}$ Faculty of Veterinary Medicine, University of Nusa Cendana, Kupang, Indonesia.
}

\begin{abstract}
Malignant catarrhal fever (MCF) is a disease causing a fatal outcome in cattle and generates economic losses worldwide. This study aims to detect the cause of the disease in Balinese cattle showing clinical signs such as high fever, serous ocular mucopurulent nasal discharges, and enlargement of pre-scapularis and pre-femoralis lymphnodes. These cattle were previously housed 50 meters away from a flock of sheep which were brought from Sabu Island 3 months earlier. Samples including blood, ocular, nasal, and vaginal swabs were collected from 22 sheep, 30 goats, 33 clinically healthy cattle (22 Balinese and 11 Ongole cattle), and 3 infected Balinese cattle. Samples were processed and tested using A nested polymerase chain reaction (PCR) test. Results showed that 12 sheep out of 22 and 3 out of 3 infected Balinese cattle were positive MCF, suggesting a potential spread of the disease from sheep to Balinese cattle. No goats and Ongole cattle that were positive indicate that these animals are less susceptible to Ovine Herpesvirus-2 (OvHV-2) infection compared to Balinese cattle. The finding of 5 positive samples from 22 healthy Balinese cattle shows the potential of sub-clinical infection of OvHV-2.
\end{abstract}

\section{Introduction}

Malignant catarrhal fever (MCF) is a viral disease which generates fatal outcome in cattle and other ruminants, characterized by fever, ocular and nasal discharge, listlessness, and death [1]. There are two types of MCF i.e. Wildebeest-associated MCF (WA-MCF) which is caused by Alcelaphine gammaherpesvirus-1 (AlHV-1) and sheep-associated MCF (SA$\mathrm{MCF}$ ) which is caused by Ovine gammaherpesvirus-2 (OvHV-2)[2]. Several animals have been reported to be more susceptible for SA-MCF, such as Balinese cattle (Bos javanicus) [3], water buffalo (Bubalus bubalis), and Bison (Bos bonasus) [4], although it has been reported in pigs, deer, and moose [5], goat [6], and horse [1]. Wildebeest and domestic sheep are

\footnotetext{
* Corresponding author: agusrini@indo.net.id
} 
reported to be natural hosts without developing clinical signs for AlHV-1 and OvHV-2 infection, respectively [2].

MCF spread throughout the world, such as in Africa [7], America [8], Europe [9], Asia [5], and New Zealand [10]. In Indonesia, this disease has been reported in Kediri in 1894 by Mansjoer in 1954 [11], and since then this disease has spread in most of the provinces in Indonesia [12]. High cases rate of MCF was reported in West Nusa Tenggara, East Java, East Nusa Tenggara, and Bali [6]. Between 2006 and 2013, there were 1751 MCF cases which were reported, with 1063 cases in cattle, 480 cases in buffalo, 201 cases in goat, 6 cases in sheep, and 1 case in pig [6].

This study was initiated by a report on the clinical diseases in Balinese cattle in a mixed large and small ruminant teaching farm in Kupang, East Nusa Tenggara, Indonesia. So that the study aims to investigate the cause of the disease that has affected and provide recommendations to the teaching farm.

\section{Materials and Methods}

\subsection{Samples collection and field observation}

Samples were collected in a farm in Kupang, East Nusa Tenggara which reported the diseases in Balinese cattle. Samples collected were heparinized blood of 33 clinically healthy cattle (22 Balinese and 11 Ongole), and 3 infected Balinese cattle, and swabs of ocular, nasal, and vaginal from 22 sheep, 3 goats, and 3 infected Balinese cattle. Samples were stored at $4^{0} \mathrm{C}$ before being processed.

\subsection{DNA extraction}

Extraction of DNA was carried out using a Genomic DNA mini kit (GeneAid, Taiwan) following the company's instruction. Briefly, $200 \mu \mathrm{l}$ samples were added to the tube containing GB Buffer and incubated at $60^{\circ} \mathrm{C}$ for at least 10 minutes. Around $200 \mu \mathrm{l}$ of absolute ethanol was added and mix for 10 seconds. The mixture was transferred into the spin column and centrifuged at 14-16,000 x g for 2 minutes. W1 Buffer was added and centrifuged at 14-16,000 x g for 30-60 seconds. Columns were washed with $600 \mu$ of wash buffer, centrifuged at $14-16,000 \mathrm{x}$ g for 30-60 seconds, and repeat for 3 minutes to dry the column matrix. Add $100 \mu \mathrm{l}$ of pre-heated Elution Buffer, leave at least 3 minutes, and centrifuged at $14-16,000 \times \mathrm{g}$ for 30 seconds to elute the purified DNA.

\subsection{Nested Polymerase Chain Reaction}

Nested polymerase chain reaction (PCR) was used according to the previous study [13], [14] and OIE recommendation [2] with minor modifications. Nested PCR was induced using AmpONE Taq DNA Polymerase (GeneAll, Seoul, Korea) following the manufacture procedure. PCR product analysis was conducted with gel electrophoresis of $5 \mu \mathrm{lPCR}$ product at $100 \mathrm{~V}$ for 1 hour in 1,5\% agarose. Visualization of product was conducted using ethidium bromide and ultraviolet trans-illuminator. 


\section{Results and Discussion}

\subsection{Clinical features}

A field investigation was conducted on the farm. Clinical signs such as high fever, serous ocular discharges, mucopurulent nasal discharges, and enlargement of pre-scapularis and pre-femoralis lymph nodes were observed in infected cattle (Fig. 1). Based on the clinical findings it was likely to be MCF. However, there were several differential diagnosis of MCF, namely rinderpest, septicemia epizootica (SE), bovine viral diarrhea-mucosal disease (BVD$\mathrm{MD})$, Bluetongue, Foot and Mouth Disease (FMD), vesicular stomatitis and plant poisoning [2], infectious bovine rhinotracheitis [15]. Also, MCF must be differentiated from Jembrana disease [12], and in buffalo, it can be confused with Surra by Trypanosoma evansi [6]
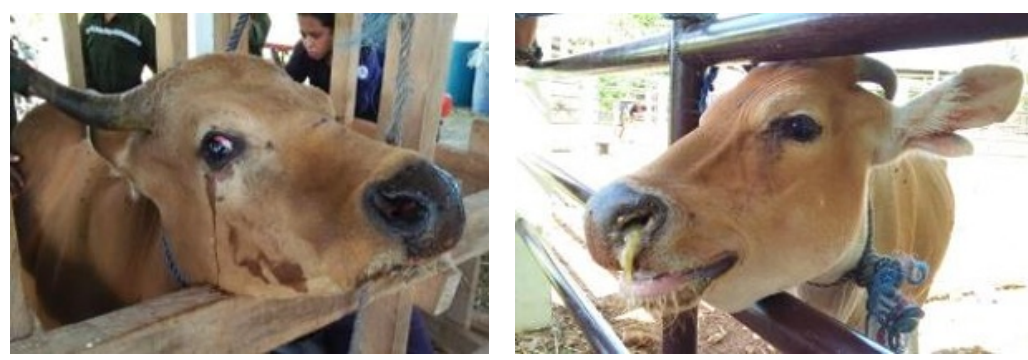

Fig. 1. Balinese cattle developed clinical signs such as serous ocular discharges and mucopurulent nasal discharges.

\subsection{Epidemiological observation}

Epidemiologically, the infected cattle were previously housed 50 meters away from a flock of sheep which were brought from Sabu Island and lambing 3 months earlier. It was the first of such disease in these farms. Ongole cattle that were penned closer to the sheep pen remained clinically healthy. SA-MCF case could occur in a Bali cow raised 100 meters from a sheepfold that was pregnant and giving birth [16]. MCF was also reported in Egypt when cattle and buffalo became infected with OvHV-2 after the presence of newly lambing ewes in the same premises [17]. Another study showed that the closer the distance to the sheepfold, the Bali cattle tend to be more likely to be infected with MCF [18]. The "safe" distance so that sensitive animals do not contract MCF from reservoir animals is not known with certainty. MCF virus from sheep farms could transmit to bison ranches that were $1-5 \mathrm{~km}$ away, however, the exact transmission mechanism is unknown but might be influenced by the age and the amount of OvHV-2 viruses, the role of aerosols (secretions containing the virus blown away by the wind), weather (wind, temperature, and humidity) and mechanical vectors such as birds [19].

\subsection{PCR detection of OvHV-2}

The PCR results (Table 1) showed that OvHV-2 has been detected in pooled swab samples of nasal, ocular, and vaginal in 12 of 22 sheep, in 5 of 21 heparinized blood samples of apparently healthy Balinese cattle; in all heparinized blood of 3 Balinese cattle showing clinical signs of MCF; and in all pooled of swab samples of nasal, ocular and vaginal of 3 Balinese cattle showing clinical signs of MCF. There was no OvHV-2 fragment detected 
from all swabs samples of cross-bred Etawa and local (Kacang) goats, nor all heparinized blood samples of apparently healthy Ongole cattle.

Table 1. Result of PCR test on heparinized blood of cattle and ocular, nasal, and vaginal pooled swab samples of goats, sheep, and cattle

\begin{tabular}{llccc}
\hline Species/Breed & \multicolumn{1}{c}{ Samples } & $\begin{array}{c}\text { Number } \\
\text { of samples }\end{array}$ & $\begin{array}{c}\text { Positive } \\
\text { PCR test }\end{array}$ & $\begin{array}{c}\text { The } \\
\text { proportion of } \\
\text { infection (\%) }\end{array}$ \\
\hline $\begin{array}{l}\text { Cross-bred Etawa } \\
\text { goat }\end{array}$ & $\begin{array}{l}\text { ocular, nasal, vaginal } \\
\text { pooled swab samples }\end{array}$ & 18 & $0 / 18$ & 0 \\
\hline $\begin{array}{l}\text { Local (Kacang) } \\
\text { goat }\end{array}$ & $\begin{array}{l}\text { ocular, nasal, vaginal } \\
\text { pooled swab samples }\end{array}$ & 12 & $0 / 12$ & 0 \\
\hline $\begin{array}{l}\text { Sheep } \\
\text { ocular, nasal, vaginal } \\
\text { pooled swab samples }\end{array}$ & 22 & $14 / 22$ & 54.55 \\
\hline $\begin{array}{l}\text { Cross-bred } \\
\text { Ongole cattle }\end{array}$ & heparinized blood & 11 & $0 / 12$ & 0 \\
\hline $\begin{array}{l}\text { Clinically healthy } \\
\text { Balinese cattle }\end{array}$ & heparinized blood & 21 & $5 / 21$ & 23.81 \\
\hline $\begin{array}{l}\text { Clinically } \\
\text { infected Balinese } \\
\text { cattle }\end{array}$ & $\begin{array}{l}\text { ocular, nasal, vaginal } \\
\text { pooled } \text { swab samples }\end{array}$ & 3 & $3 / 3$ & 100 \\
\hline
\end{tabular}

Based on the PCR results, it was obvious that the Balinese cattle had been previously infected by OvHV-2 secreted by lambing sheep. In this case, goats (cross-bred Etawa and local (Kacang)) were unlikely to be the sources of infection since they were free from OvHV2. Most of the sheep are not infected until 2 months of age. If the sheep are separated from infected sheep before 2 months of age, they remain uninfected and can be raised as virusfree sheep. Both juvenile and adult sheep shed viruses primarily through nasal secretions [20]. Sheep aged between 6 and 9 months shed the virus more frequently and more intensely, which suggests that the likelihood of transmission from adult sheep is relatively stable and low throughout the year [8] This is scientific-based for sheep producers and also zoos with large ruminant susceptible to MCF and sheep population to produce OvHV-2 free sheep. This may also be applied in this teaching farm to have both Balinese cattle and sheep population on the same premises.

The PCR results also showed that among so-called healthy Balinese cattle, some of them were apparently infectedinfectd by OvHV-2 without showing any clinical signs. Normally, OvHV-2 infection in cattle is caused by a cell-associated virus that survives 72 hours outside the host whereas the cell-free virus is inactivated quickly in dry environments but may survive over 13 days in humid environments [2]

In this case of OvHV-2 was detected in samples of pooled swabs of nasal, ocular, and vaginal of sick cattle, the virus is likely originated from peripheral blood leucocyte (PBL) existed in the opaque cornea of sick cattle. A previous study reported that OvHv-2 DNA was detected in specimens from PBL sheep and goats [14]. 


\section{Conclusion}

Based on the clinical-epidemiological features, and confirmed by PCR results, it was concluded that the Balinese cattle had been previously infected by OvHV-2 secreted by lambing sheep and that OvHV-2 sub-clinical infection was likely to occur in clinically healthy Balinese cattle population in this teaching farm. It is recommended to the teaching farm establish a flock of OvHV-2-free sheep.

\section{References}

1. R. Sood, R. Khandia, S. Bhatia, D. Hemadri, M. Kumar, S.S. Patil et al., Detection and molecular characterization of naturally transmitted sheep associated malignant catarrhal fever in cattle in India, Trop Anim Health Prod 46 (2014)

2. OIE, Chapter 2.4.14. Malignant Catarrhal Fever. (http://www.oie.int/fileadmin/Home/eng/Health_standards/tahm/2.04.14_MCF.pdf)

3. Z. Zamila, Z. Azila, A. Shuhaini, A. Esdy and M. Yusniza, Malaysian J. Vet. Res. 2, 3539 (2011)

4. H. Li, A. Brooking, C.W. Cunha, M.A. Highland, D. O'Toole, D.P. Knowles et al., Vet. Microbiol. 159, 485-489 (2012)

5. D. O 'Toole and H. Li, Vet. Pathol. 51, 437-452 (2014)

6. R. Damayanti, Wartazoa 26, 103-114 (2016)

7. L. Wambua, P.N. Wambua, A.M. Ramogo, D. Mijele and M.Y. Otiende, Arch. Virol. 161, 1-10 (2016)

8. H. Li, C.W. Cunha and N.S. Taus, Int. J. Mol. Sci. 12, 6881-6893 (2011)

9. D. O'Toole and H. Li, Vet Pathol 51, 437-452 (2014)

10. A. Kirbas, E. Oruc, Y. Ozkanlar, I. Sozdutmaz, M.S. Aktas and Y.S. Saglam, Isr. J. Vet. Med. 68, 195-200 (2013)

11. P. Daniels, Sudarisman and P. Ronohardjo, Malignant Catarrhal Fever in Asian Livestock (1988), pp. 1-131

12. I.W.M. Tenaya, K. Heel, P.A. Stumbles and G.E. Wilcox, Vet. Immunol. Immunopathol. 149, 167-176 (2012)

13. S.I.F. Baxter, I. Pow, A. Bridgen and H.W. Reid, Arch Virol 132, 145-159 (1993)

14. A. Wiyono, S.I.F. Baxter, M. Saepulloh, R. Damayanti, P. Daniels, H.W. Reid, Vet. Microbiol. 42, 45-52 (1994)

15. R. Damayanti and Sudarisman, J. Ilmu Ternak dan Vet. 10, 227-235 (2005)

16. A. Wiyono and R. Damayanti, J. Ilmu Ternak dan Vet. 4, 128-135 (1999)

17. A.A.. Zaki, H.. El-Said, A. Abd El-Aziz, M. Iman, M. Bastawecy, A. Shahira et al., Life Sci. J. 13, 83-98 (2016)

18. A. Wiyono and R. Damayanti, J. Vet. 19, 419-429 (2018)

19. H. Li, G. Karney, D. O’Toole and T.B. Crawford, Can. Vet. J. 49, 183-185 (2008)

20. H. Li, N.S. Taus, G.S. Lewis, O. Kim, D.L. Traul and T.B. Crawford, J. Clin. Microbiol. 42, 5558-5564 (2004) 